\title{
Metáforas da navegação na lírica brasileira contemporânea de autoria feminina
}

\author{
Rafael Quevedo*
}

\section{Resumo}

Propõe-se uma reflexão acerca do emprego de uma metáfora pertencente ao patrimônio da poesia ocidental, a metáfora náutica, na obra das poetas brasileiras contemporâneas Ana Cristina Cesar (1979), Orides Fontela (1983), Neide Archanjo (1984), Hilda Hilst (1989) e Maria Lúcia dal Farra (2012). Para esse objetivo, discute-se o arcabouço simbólico do tema náutico e da metáfora marinha, verificam-se casos exemplares de seu emprego colhidos da tradição e, por fim, parte-se para a análise do corpus tentando averiguar possíveis deslocamentos, variações e marcas que sirvam como indício de uma reconfiguração feminina da metáfora poética da viagem marítima.

Palavras-chave: Metáfora Náutica. Poesia brasileira contemporânea. Autoria Feminina.

* Universidade Federal do Maranhão (UFMA). Doutor em Literatura pela Universidade de Brasília (UnB); mestre em Letras pela Universidade Federal do Espírito Santo (UFES). É Professor Adjunto do Departamento de Letras da Universidade Federal do Maranhão (UFMA), professor do Programa de Pós-Graduação em Letras da UFMA (PGLetras-UFMA). 


\title{
Navigation Metaphors On Brazilian Contemporary Lyric Of Female Authorship
}

\begin{abstract}
It is proposed a reflection upon the use of a metaphor which is part of the western poetry heritage, the nautical metaphor, on the works of brazilian contemporary female poets Ana Cristina Cesar (2013), Orides Fontela (1983), Neide Archanjo (1984), Hilda Hilst (1989) and Maria Lúcia dal Farra (2012). For this aim, it is discussed the symbolic framework of the nautical topic and the marine metaphor, it is observed model cases of its use derived from tradition and, lastly, we set sail for the analysis of the corpus attempting to inquire possible shifts, variations and marks which can become a sign of a female reset of the sea travel poetic metaphor.
\end{abstract}

Keywords: Nautical Metaphor. Brazilian Contemporary Poetry. Female Authorship.

Recebido em: 14/07/2020 // Aceito em 23/11/2020 
I

O epigrama X: 65 do grego Paladas de Alexandria, aqui transcrito na tradução de José Paulo Paes, é um dos tantos remotos registros literários do emprego da metáfora náutica:

Navegação perigosa, a vida: em meio às tempestades, somos às vezes mais de lastimar que náufragos.

Tendo como piloto de nossas vidas a Fortuna, incertamente é que vogamos no mar alto; uns fazem boa viagem, outros ao contrário, mas todos chegam ao mesmo porto sob a terra.

(PALADAS DE ALEXANDRIA, 2001, p. 67)

A articulação metafórica entre vida e navegação é um daqueles lugares-comuns da poesia que parecem não sofrer desgaste. Seja se nos deparamos com a Fortuna ao leme, como no caso do epigrama citado, seja na ausência de quem se acha "andando em bravo mar, perdido o lenho" na bela associação entre a viagem marítima desgovernada e o desassossego amoroso em Camões, seja, enfim, nos poemas contemporâneos que compõem o corpus deste artigo, o tema da aventura marítima foi e continua sendo objeto de diversas apropriações. Nos textos medievais dos Carmina Burana a paixão comparada à situação de estar à deriva já se fazia presente:

Tanta gente

balança em sua mente

quando o assunto é amor;

a jangada, a âncora faltando,

nas ondas vai vagando:

assim a esperança ou o medo agita

quem por Vênus milita.

(CARMINA BURANA, 1994, p. 43) 
Figura entre os exemplos paradigmáticos de seu emprego na lírica portuguesa o soneto de Camões, transcrito a seguir, cuja herança petrarquista ${ }^{1}$ do amor como experiência perturbadora teve inegável presença na configuração que o português quinhentista deu ao topos:

Busque Amor novas artes, novo engenho, para matar-me, e novas esquivanças; que não pode tirar-me as esperanças, que mal me tirará o que eu não tenho.

Olhai de que esperanças me mantenho! Vede que perigosas seguranças! Que não temo contrastes nem mudanças, andando em bravo mar, perdido o lenho.

Mas, conquanto não pode haver desgosto Onde a esperança falta, lá me esconde Amor um mal, que mata e não se vê.

Que dias há que n'alma me tem posto Um não sei quê, que nasce não sei onde, Vem não sei como, e dói não sei porquê. (CAMÕES, 2006, p. 85)

Atentemos, entretanto, para um fator importante nessa associação: o leme do barco (leia-se, a condução da vida) escapa ao controle do timoneiro tanto no caso do poema grego (cuja condução da nau está a cargo da Fortuna) quanto no eu poético camoniano, à deriva, como vimos, devido à angústia amorosa, esse tão conhecido "não sei quê, que nasce não sei onde,/vem não sei como, e dói não sei porquê." Insistamos, portanto, no valor

1 O poema de Camões dialoga bastante de perto com o seguinte soneto de Petrarca no qual a paixão, experiência dilemática e conflituosa, é comparada a estar numa barca sem governo: "Se amor não é, qual é meu sentimento? Mas se ele é amor, por Deus, que coisa é e qual?/Se boa, de onde lhe vem a ação moral?/Se má, por que é tão doce o seu tormento?//Se eu ardo por querer, por que lamento?/Se a meu mau grado, lamentar que val?/Ó viva morte, ó deleitoso mal,/tanto em mim podes sem consentimento.//E se eu consinto, sem razão pranteio./Em tão contrário vento, em frágil barca/me encontro em alto mar e sem governo;//vazia de saber, de erro ela se arca,/tanto que não sei bem o que anseio,/e tremo no verão e ardo no inverno. (PETRARCA, 2014, p.239). Cf. também, sobre esse mesmo tema, o soneto "Meu navio passa pleno de olvido". 
simbólico inscrito no cerne da metáfora para cuja elucidação poderá contribuir o seguinte trecho de um conhecido dicionário de símbolos:

O processo psicológico adota frequentemente a metáfora do navio e da viagem - estabelecer um objetivo e seguir um curso, descobrir onde estamos em relação ao centro, a viagem do herói mítico que confere circum-navegação consciente dos aspectos não traçados da personalidade. "Navio" é há muito uma analogia para um todo que depende da cooperação das partes e do que é governado por um "capitão". A filosofia clássica retratou o corpo humano como um navio no qual a alma ponderada é o timoneiro. $\mathrm{O}$ estado é retratado como um navio, no qual os bons cidadãos cooperam para assegurar a sua prosperidade. A Igreja cristã é comparada a um navio, cujo mastro é a cruz ou o campanário. O naufrágio sugere assim um vaso puxado para o vórtice das energias demasiado esmagadoras de suportar, ou um vaso cuja estrutura é inerentemente instável ou é destruído nas rochas mortais das atitudes malignas, da má liderança do "capitão" ou da ineficácia ou anarquia da "tripulação". (MARTIN, 2012, p. 452)

A passagem como um todo interessará ao curso destas reflexões. Porém, um trecho, em especial, requer maior atenção já nestes primeiros passos: "Navio" é, há muito, um dos termos de uma analogia para um todo que depende da cooperação das partes que o compõem e, sobretudo, de quem as capitaneie. Assim, visto no detalhe, esse importante aspecto simbólico da metáfora lança ainda mais luz sobre os poemas ora referidos. Em se tratando de um caso de subordinação entre aquele que governa e os governados, é sobre uma relação de poder que se estrutura a metáfora. É preciso subjugar as paixões, diria o filósofo grego, pois a alma é como um barco e a razão deverá empunhar o leme a fim de evitar o naufrágio. Como no exemplo de Camões e seu intertexto petrarquista, o corpo é uma barca frágil, à mercê da 
impetuosidade do mar, leia-se, a força das paixões.

Torna-se, assim, mais visível a problemática nuclear que a metáfora náutica encerra: a tensão entre, de um lado, o imprevisível e as adversidades e, de outro, a arte de capitanear, de garantir o equilíbrio e o êxito da travessia. Tal esquema simbólico permite com que a metáfora possa ser empregada nos mais diversos âmbitos, não apenas no psicológico, no político e no religioso, tal como informado na citação acima, mas também em outras esferas, como a da composição poética, conforme veremos mais adiante.

Entretanto, tais aspectos constitutivos da metáfora náutica permitem entrever uma outra ordem de questões que aqui se fará presente dada a particularidade do corpus abordado, a saber: em se tratando de poemas escritos por mulheres, é possível observar uma transfiguração significativa da matéria metaforizada? A autoria feminina desarticula de algum modo o esquema de “capitaneamento" de forças, tão marcadamente masculino? Tais indagações atravessam estas considerações que servirão, se não para encerrá-las, pelo menos para fornecer alguns elementos que possam, assim esperamos, ajudar a formulá-las melhor.

$\mathrm{Na}$ seção a seguir, portanto, examinamos alguns casos emblemáticos do emprego da metáfora náutica em domínios tradicionalmente pouco habitados pela presença feminina. A ideia é montar um quadro representativo, ainda que sumário, do lugar da mulher dentro da temática em questão para, no tópico posterior, partir para a análise do corpus composto por poetas brasileiras cujas obras, escritas entre 1980 e 2012, trataram do topos náutico. 
II

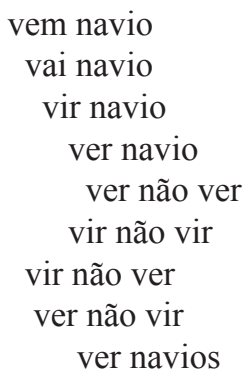

(CAMPOS, 2008, s/p)

Consta nos relatos de Plutarco, o historiador, o episódio de Pompeu que, encarregado de fazer um transporte de trigo até Roma, partindo do Egito, deparou-se com condições meteorológicas extremamente adversas. Sob clamores de amigos para que não embarcasse, teria respondido o magistrado romano que navegar é necessário, viver não é necessário.

Dante Tringali (1995), importante latinista e tradutor brasileiro, identifica na obra de Horácio um ponto de vista diametralmente oposto ao do arrojado Pompeu. Sua obra conteria, portanto, uma mensagem inversa, ao propor que o mais importante é viver e que viajar é não apenas desnecessário, como ameaçador a tudo que verdadeiramente importa na vida:

O que importa é viver bem, morando num lugar seguro, de preferência no campo, desfrutando o dia, o dia que passa. Não o seduzem as viagens, máxime, por mar. Não gostaria de viver perigosamente, como Nietzsche! Em vez de viajar, apraz-lhe gozar os ingênuos prazeres do lirismo que derivam do ócio, de um doce ócio, onde nas festas se celebra o festim. (TRINGALI, 1995, p. 153-154)

Outra informação a respeito do longínquo tema literário da 
viagem marítima nos é dada pela valiosa obra de Ernst Robert Curtius, o Literatura europeia e Idade Média latina (2013), em seu estudo sobre a "metáfora náutica": o ato de navegar associado à escrita de uma obra literária. Os exemplos arrolados pelo filólogo alemão mostram tratar-se de um lugar-comum da "tradição poético-retórica da latinidade medieval" o referir-se à escrita de um poema como equivalente metafórico de uma viagem marítima: "o poeta torna-se marinheiro; e seu espírito ou sua obra, o barco" (CURTIUS, 2013, p.176). Assim escreveu Dante, por exemplo, no "Purgatório" (I, 1 e ss.): "A singrar melhor água eis que o batel/De meu engenho segue, a vela inflada". Segundo Curtius, na época de Dante a metáfora já se encontrava cristalizada como um topos cujas raízes, entretanto, remontam à Antiguidade latina, tal como atestam os trechos de Virgílio, Ovídio, Manílio, Estácio, entre outros citados na referida obra. Em tais autores encontram-se formulações que se referem à composição poética como ato de velejar, ao poeta épico como aquele que "viaja num grande navio sobre o largo mar; o lírico numa pequena canoa e pelo rio." (CURTIUS, 2013, p.175) ou a alusão ao início da obra como o ato de "soltar as velas". O término do trabalho de criação literária é referido como ato de recolhimento das velas e, por fim, as dificuldades da escrita são associadas aos percalços e perigos da navegação.

O terceiro emprego da navegação na literatura nos é ainda particularmente importante para a produção de língua portuguesa: trata-se da aventura marítima como motivo épico, já conhecido da Antiguidade, mas que ganhou em Camões uma dimensão especial. Nesse âmbito, o que se afigura relevante aos nossos propósitos é que os percalços e perigos, bem como o êxito da viagem, permitem-se ser lidos como extensão de valores e 
qualidades masculinos, como se pode depreender de um rápido apanhado semântico apenas das estâncias que compõem a proposição do grande épico lusitano: "barões assinalados", "perigo", "guerra", "força", "edificaram", "dilatando", "devastando", o que nos autoriza concluir que o próprio fator heroico é constituído por elementos marcadamente masculinos.

Coloquemo-nos, portanto, a conjecturar acerca do lugar da mulher nas situações acima descritas a começar pela última, a poesia épica, levando em consideração o exemplo que nos é mais próximo, Os Lusíadas. Tomemos, para tais fins, a seguinte consideração de Christina Ramalho em seu livro Elas reescrevem o épico:

[...] Em contraposição à figura do herói, a figura da mulher tinha seu papel em duas dimensões paralelas; ou eram deusas e musas, atuando na dimensão mítica, ou eram mulheres, mortais, atuando na dimensão real. Em ambas as dimensões, sua função era contribuir para o heroísmo do homem, quer por uma influência positiva, que por uma influência negativa, ou seja, tanto através do amor, quanto através do ódio, as figuras femininas serviam de instrumento para a formação do herói. Paralelamente, tínhamos também a figura feminina da musa inspiradora atuando sobre o poeta, contando, através dele, o percurso do herói. [...] (RAMALHO, 2003, p. 207-208.)

Desse modo, tem-se a atuação feminina em Os Lusíadas situada, por assim dizer, num lugar que ladeia a ação heroica, contribuindo para seu êxito em pelo menos três planos: o plano metapoético (a invocação às tágides por parte do narrador), o plano mítico (a importante contribuição de Vênus para os lusitanos), o plano diegético (o episódio de Inês de Castro) e, ainda, um plano simbólico/utópico (o papel das ninfas no encontro amoroso com os navegantes, especialmente de Tétis 
como mediadora da epifania da máquina do mundo no episódio final do poema). Trata-se, como se vê, de uma importância que se poderia chamar de coadjuvante à ação épica.

Em se tratando, por sua vez, do lugar do feminino na poesia tradicional sobre navegação é talvez possível aplicar o mesmo conhecido adágio dos marinheiros sobre a mulher não ser bemvinda a bordo, o que também se deixa verificar no exemplo da metáfora náutica estudada por Curtius, uma vez que, levando em consideração um contexto de produção literária majoritária ou eminentemente masculina (como é o caso do romano, onde a metáfora se cristaliza), não há sequer o que possa ser trasladado do plano real para o plano figurado e que sirva como indício para se pensar marcas de autoria feminina figuradas na metáfora da escritura poética como navegação.

Outros tantos exemplos colhidos da poesia portuguesa poderiam ser evocados a fim de situar o lugar feminino à margem do protagonismo quando o que está em jogo é a viagem marítima na poesia. Apenas mais um, pelo que há de emblemático na sua imagem: A conhecida cantiga de amigo de Martim Codax "Ondas do mar de Vigo":

Ondas do mar de Vigo,
se vistes meu amigo!
e ai Deus, se verrá cedo!
Ondas do mar levado,
se vistes meu amado!
e ai Deus, se verrá cedo!

Se vistes meu amigo,

o por que eu sospiro!

e ai Deus, se verrá cedo!

Se vistes meu amado, o por que hei gram cuidado! 
e ai Deus, se verrá cedo? ${ }^{2}$

(CODAX, 1998, p. 68)

Lê-se o apelo do sujeito lírico feminino e seu endereçamento ao mar: "vistes meu amigo/amado?" de onde se subentende ter o amado partido em viagem marítima, colocando essa mulher ficcional numa outra figuração do lugar feminino, este eminentemente passivo, a saber: o da espera pelo homem que partiu em viagem marítima, cuja figura mais arquetípica é sem dúvida a fiel Penélope de Homero (vinte anos à espera do retorno do amado Odisseu). O tema foi lembrado por Chico Buarque e Dorival Caymmi ${ }^{3}$ nas canções "Mulheres de Atenas" e "É doce morrer no mar", respectivamente, e, em outra configuração (o do sofrimento materno), por Fernando Pessoa em "Mar português": “Ó mar português, quanto do teu sal/ São lágrimas de Portugal/ Por te cruzarmos quantas mães choraram [...]" (PESSOA, 2001, p. 48). Tais exemplos já bastam para completar o quadro que pretendemos apresentar da "mulher a ver navios", leia-se: o lugar da mulher na poesia tradicional de temática relacionada à viagem marítima. Com o risco de algumas simplificações, esses lugares poderiam ser assim designados: 1 - o não-lugar (ou seja, a inexistência ou escassa representatividade feminina no quesito autoria); 2 - o lugar da espera: representação do feminino à espera do retorno do amado; 3 - o lugar coadjuvante em que personagens femininas orbitam em torno do protagonismo masculino atuando com maior ou menor importância, a depender

\footnotetext{
2 Na tradução de Natália Correia: "Ai ondas do mar de Vigo,/se vistes o meu amigo,/dizei-me: voltará cedo?//Ondas do mar levantado/se vistes o meu amado,/dizei-me: voltará cedo?//Se vistes o meu amigo,/aquele por quem eu suspiro/dizei-me: voltará cedo?//Se vistes o meu amado,/que me pôs neste cuidado,/dizei-me: voltará cedo?" (CORREIA, 1998, p. 69)

3 A canção de Caymmi está sem dúvida mais próxima do esquema retórico das cantigas de amigo: "A noite que ele não veio foi/ Foi de tristeza pra mim/Saveiro voltou sozinho/Triste noite foi pra mim/É doce morrer no mar..." (CAYMMI, 1943). A letra de Chico Buarque, entretanto, é mais enfática quanto ao papel da submissão feminina: "Quando eles embarcam soldados/Elas tecem longos bordados/Mil quarentenas/E quando eles voltam, sedentos/Querem arrancar, violentos/Carícias plenas, obscenas/ [...] Elas não têm gosto ou vontade/Nem defeito, nem qualidade/Têm medo apenas/Não tem sonhos, só tem presságios/O seu homem, mares, naufrágios/Lindas sirenas, morenas [...]" (HOLLANDA, 1976)
} 
do caso.

III

Passamos agora ao segundo momento deste artigo dedicado à poesia contemporânea de autoria feminina e à hipótese da redistribuição ou recolocação dos lugares do feminino nessa produção poética. O corpus selecionado é composto de sete poemas, pela ordem: “Amor” de Maria Lúcia dal Farra (2012), “Odes" e "Nau III” de Orides Fontela (1983), "Recuperação da adolescência" e "nada, esta espuma" de Ana Cristina Cesar (1979), o poema XVII do livro Amavisse (1989) de Hilda Hilst e um fragmento do II canto do poema épico-lírico de Neide Archanjo, As marinhas de 1984. Aqui será empregada a leitura cruzada dos poemas, no intuito de detectar as intersecções de seus campos semânticos que se deixam apreender como releituras dos lugares da tradição arrolados anteriormente. Devido à estratégia de leitura empregada que exige o cruzamento dos poemas entre si, optamos por transcrevê-los todos de uma única vez e, em seguida, estabelecer os comentários. A numeração dos poemas tem como intenção facilitar ao leitor os cotejos e os paralelos que serão propostos, bem como a localização das citações.

\title{
1. AMOR
}

\author{
A hipótese de navegação \\ reside sempre \\ em acordos tácitos: \\ da maré com o sol, com a lua, \\ do sal com a palma das mãos \\ (harmoniosas no mergulho).
}

Para além destes 
é preciso saber dos ventos, da tensão das rochas, do equilíbrio dos fundos.

Só então estabelecer a rota e guiar-se em direção a quantos naufrágios a vontade do mar permitir.

(DAL FARRA, 2012, p. 24)

2.

No mar interior em que olhosvivências se tramam no mar estruturado de olhares em que a vida se adensa, não há falhas

e onde tudo é vivo nenhum barco furtivo se aventura.

Reteso o arco e o sonho espero: nada mais é preciso.

(FONTELA, 2006, p. 172)

3. NAU (II)

Um barco

fende - tranquilo - o mar

(o amor) transporta

- voo profundo - o esplendor

do silêncio.

Um barco

fende o rumor do mar

transporta

— silente ânfora - a

imortal lucidez do branco

a

siderante impossível 
primavera.

(FONTELA, 2006, p. 183)

4.

recuperação da adolescência

é sempre mais difícil

ancorar um navio no espaço

(CESAR, 2013, p. 17)

5.

nada, esta espuma

Por afrontamento do desejo

insisto na maldade de escrever

mas não sei se a deusa sobe à superfície

ou apenas me castiga com seus uivos.

Da amurada deste barco

quero tanto os seios da sereia.

(CESAR, 2013, p. 27)

6.

As barcas afundadas. Cintilantes

Sob o rio. E é assim o poema. Cintilante

E obscura barca ardendo sob as águas.

Palavras eu as fiz nascer

Dentro da tua garganta.

Úmidas algumas, de transparente raiz:

Um molhado de línguas e de dentes.

Outras de geometria. Finas, angulosas

Como são as tuas

Quando falam de poetas, de poesia.

As barcas afundadas. Minhas palavras.

Mas poderão arder luas de eternidade.

E doutas, de ironia as tuas

Só através da minha vida vão viver.

(HILST, 2017, p.450)

7.

A mão que trabalha agora sobre o papel

poderia construir barcos

que depois empurraria mar adentro.

os dedos seguram o lápis como um leme

e o papel, água lisa e limpa, 
espera os ventos.

Escolhi uma matéria

para exercer o meu ofício:

o mar

e ando contando suas gotas.

Lavor admirável o meu

metida nesses abismos

onde a lógica cartesiana

ou a consciência rondam apenas

a borda e a superfície.

O fundo é pedra filosofal.

Terra: $3 / 4$ de água. Escapar como?

(ARCHANJO, 1984, p. 38)

Baseado num critério temático, é possível dividir os poemas selecionados em dois grupos: o primeiro, que estabelece um cruzamento entre a navegação e a temática amorosa (poemas 1, 3 e 4) e o segundo que aproxima a metáfora náutica da reflexão metalinguística $(2,5,6$ e 7). Tal divisão mostra-se, entretanto, assumidamente imperfeita, pelos seguintes motivos. Em primeiro lugar, o poema de Hilda Hilst deveria se situar na interseção entre o primeiro e o segundo grupo na medida em que, embora pareça dominante o fator metalinguístico do poema, a criação poética aparece associada a um amor carnal ("um molhado de línguas e de dentes"), fazendo o poema deslizar, portanto, para a temática amorosa. Por outro lado, o dístico "recuperação da adolescência", a rigor, não se encaixaria em nenhum agrupamento. Optamos, meio arbitrariamente, por inseri-lo no primeiro, levando em consideração a sugestão fornecida pela palavra "adolescência", aqui associada às primeiras experiências no campo das aventuras amorosas. Por fim, o poema 3 também pode ser lido pela ótica da metáfora náutica como escrita do poema, tal como tentaremos demonstrar mais adiante. Em ambos os grupos, portanto, encontra-se formulada, de alguma maneira, 
a tensão entre, de um lado, o inesperado/imprevisível e, de outro, o cálculo/planejamento dos riscos, remetendo esse tipo de poesia ao antigo dilema ilustrado pela oposição Pompeu/Horácio. Em suma: trata-se de figurar tanto o fazer poético quanto a investida amorosa, como formas de aventura. Vejamos como isso se dá nos poemas do primeiro grupo.

O título ("Amor") do poema de Dal Farra fornece a chave por meio da qual devemos entender a metáfora da navegação (verso 1) por ela desenvolvida. A aventura marítima pressupõe um plano prévio (previsão) a ser estabelecido entre os fatores que lhe dizem respeito, muito embora o eu lírico se mostre cônscio do naufrágio que lhe espera.

O poema "Nau II" de Fontela também lida com a identificação entre navegação e amor explicitada na intromissão da palavra no terceiro verso, quebrando o esquemático e quase geométrico paralelismo entre as duas primeiras estrofes e decifrando, por assim dizer, a metáfora em jogo. De maneira semelhante ao poema de Dal Farra, este se encerra, também, com uma nota de fatalismo, análoga ao naufrágio do primeiro, na medida em que se fala sobre uma "siderante impossível primavera". A julgar tanto pelo caráter fulminante, aniquilador ou atordoante (acepções possíveis para o termo "siderante"), quanto pelo taxativo adjetivo "impossível", tem-se que a primavera, estação associada ao florescimento (inclusive da própria poesia ${ }^{4}$ ) permanece inviável.

$\mathrm{O}$ dístico de Ana Cristina Cesar que, por inferência, foi aqui associado à temática amorosa, permite ser lido, em sentido mais amplo, como metáfora da instabilidade ou suprema falta

\footnotetext{
4 Menciono aqui a irônica passagem da Carta aos Pisões em que Horácio alega não ser bom poeta por "não purgar a bile quando da chegada da primavera" e também a investida irônica do rei trovador Dom Dinis contra o trovadorismo provençal que só "trobam no tempo da flor". Sua poesia seria, portanto, mais sincera, dado que independe da estação do ano para expressar o amor.
} 
de ancoragem na vida, numa condensada representação do que é estar à deriva, existencialmente falando.

É da imprecisão ou do fracasso dos "acordos" (poema 1) e da "lucidez" (poema 3) que tratam os poemas do primeiro grupo, como a sinalizarem para o risco que é a travessia da vida ou do encontro amoroso com o outro, pois ambos guardam elementos da ordem do imponderável (o rumo dos ventos, as profundidades, as rochas etc.). Nesse sentido, os poemas em questão parecem recuperar o dilema Pompeu/Horácio menos pelo impasse por eles estabelecido (sobre ser necessária ou não a viagem) do que pela leitura que Pessoa deu ao tema em seu "Palavras de pórtico" ao traduzir o antigo adágio não como "viajar é necessário, viver não é necessário", mas sim como "navegar é preciso, viver não é preciso", enriquecendo a frase com a ambiguidade do termo "preciso" que pode ter o valor tanto de necessidade, condizente com o original latino, quanto de precisão, mais próximo do sentido observado nos poemas das autoras. Nas entrelinhas dos poemas comentados tem-se, portanto, que o amor e a vida são "viagens" imprecisas, aventuras que não se deixam premeditar ou planejar previamente.

Os poemas que compõem o segundo grupo poderiam ser abordados, assim propomos, como releituras da metáfora náutica de base metalinguística, conforme assinala Ernst Curtius. O mar surge como metáfora da interioridade no poema 2, tema contraditoriamente ao mesmo tempo eletivo ("escolhi uma matéria [...] o mar”) e inescapável (“escapar como?”) no poema 7 e imperativo no poema 5 ("por afrontamento do desejo/ insisto na maldade de escrever"). Por fim, no poema 6, o rio (e não o mar onde as barcas navegam) identifica-se com o próprio suporte do poema, a folha, sob a qual as palavras existem como 
barcas afundadas. Chama a atenção a dúbia representação da poesia a um só tempo como discurso malogrado, figurado na ideia do naufrágio que aí aparece como "barcas afundadas", e o poder imortalizador da poesia ("minhas palavras [...] poderão arder luas de eternidade"), antigo topos a que tantos poetas recorreram.

Convém atentar, também, para algo que se refere ao âmbito da criação poética propriamente dita e que aparece em alguns desses exemplos (nos poemas 2, 3, 5 e 7) na forma da vitória do imponderável sobre o cálculo ou, se quisermos, da inspiração ("reteso o arco e o sonho/ espero...", poema 2; "espera os ventos", poema 7; "se a deusa sobe a superfície", poema 5) sobre a elaboração consciente.

No poema 7, ao referir-se à poesia como "lavor admirável", a fórmula soa arcaizante no que ecoa tanto das lições horacianas sobre o trabalho de lapidação do poema quanto da profissão de fé bilaquiana. Logo em seguida, as expressões "lógica cartesiana" e "consciência" completam o campo semântico da criação como trabalho consciente, campo esse logo posto por terra (ou seria melhor dizer, por água abaixo) nos últimos versos onde se lê que essas coisas “... rondam apenas/ a borda e a superfície já que ao fundo pertence o que é da ordem do insondável e do misterioso, justamente o lugar onde está guardada a pedra filosofal $1^{5}$ : "Escapar como?". Há ainda a considerar o "nada mais é preciso" que encerra o poema 2 e que se deixa ler na ambiguidade conferida ao termo pela tradução pessoana, ou seja, nas profundezas do "mar interior" impera a imprecisão da aventura ou nada mais é necessário quando se dispõe do "arco retesado" e do "sonho".

Por fim, o poema 5 recupera o homérico tema sirênico,

5 Desnecessário lembrar que o símbolo alquímico da "pedra filosofal" associa-se ao poder de transmutar metais comuns em ouro. O paralelo com a criação poética é, portanto, evidente. 


\section{Rafael Quevedo}

subvertido em seu sentido original. No poema de Ana Cristina Cesar, o eu lírico se diz colocado na amurada do barco desejando "os seios da sereia". Nesse sentido, a inversão consistiria no fato de que as sereias, tradicionalmente representadas como aquelas que desencaminham da viagem e não as que a orientam aparecem, agora, como objetos do desejo do eu lírico que se vê em meio a uma crise de criação poética.

Finalizamos aqui a leitura cruzada dos poemas cônscio, todavia, de que o que foi alinhavado não esgota as possibilidades interpretativas. Passemos, então, às conclusões acerca do que foi colocado.

\section{IV}

As três principais condutas anteriormente assinaladas como tradicionais no que diz respeito ao lugar do feminino na poesia que abordava a metáfora náutica, a saber, o não-lugar, o lugar da espera e o lugar de coadjuvante, parecem expurgadas dos poemas aqui comentados. Independentemente de ser ou não um efeito, no texto, de um fator extratextual, ou seja, sem querer afirmar uma relação causal entre, de um lado, a apropriação de um temário historicamente masculino por parte de escritoras mulheres e, de outro, os deslocamentos e variações observados na construção das metáforas náuticas nesses poemas, interessa, neste momento do trabalho, pensar de que maneira se coloca o feminino no universo desses sete poemas.

Convém observar, portanto, que apenas um dos poemas possui, marcadamente assinalado, um traço de gênero. Trata-se do verso "metida nesses abismos", do poema de Archanjo (n.7). Nos demais, os contornos do lugar da voz feminina são menos 
nítidos, exceto se considerados a partir das obras em que estão inseridos. Nesse caso tornar-se-ia mais fácil rastrear uma unidade da voz lírica feminina em algumas obras como As marinhas, Alumbramentos, Amavisse e talvez menos em Alba e Cenas de abril.

Entretanto, chama a atenção a diferença na maneira de dispor a interrelação entre o masculino e o feminino ao longo das imagens empregadas. Destacamos, portanto, esse aspecto como principal ponto destas considerações finais e como o mais significativo da reconfiguração da metáfora náutica que se pode observar no corpus aqui abordado.

Talvez não seja gratuita a alternância de substantivos masculinos e femininos alternados nos versos do poema "Amor" (n.1) exatamente na passagem (do verso 4 ao 10) em que o eu lírico fala dos "acordos tácitos" para se consumar a "navegação" amorosa. Ei-los na ordem em que aparecem: "maré" (feminino) - "sol" (masculino) - "lua" (feminino) - "sal" (masculino) "palma das mãos" (feminino) - "ventos" (masculino) - "tensão das rochas" (feminino). Para além de uma alternância sugestiva do ir e vir das ondas, aparece aí, a nosso ver, outra sugestão importante: a metáfora náutica apresenta-se, nesse e nos demais poemas, fincada numa intersubjetividade radical entre o eu poético e o outro, ao passo que nos exemplos estocados pela tradição nota-se uma tendência ao apagamento do outro. Expliquemos. No comentário à citação extraída d'O livro dos símbolos, procuramos assinalar a ideia de relação de poder que a metáfora náutica carrega consigo em grande parte das suas formulações. A figura do timoneiro, em suas diversas manifestações (a razão para o corpo, o autor para a elaboração do poema, o herói na arriscada viagem marítima etc.), representa aquele que capitaneia a nau e, 
ainda que ela dependa da "cooperação das partes" (MARTIN, 2012, p. 452), quase sempre é a força do "capitão" que prevalece sobre as demais (as paixões da alma, os entraves da criação literária, os obstáculos da aventura etc.).

De maneira sensivelmente diversa, uma leitura atenta dos poemas escolhidos revela a ênfase no entrecruzamento das subjetividades, ou seja, nos trânsitos entre o eu poético e o outro. O poema de Orides Fontela (n.2), por exemplo, traz a seguinte passagem (do verso 2 ao 4): "olhosvivências se tramam/no mar estruturado/ de olhares [...]”. Uma vez mais, num poema em que o estofo da metáfora náutica é a questão amorosa, o eu lírico opta por se referir ao mar em termos de "trama", tanto no entrelaçamento de olhares, quanto na solução icônica para a ideia de intersubjetividade encontrada na palavra-valise "olhosvivência".

No segundo poema de Fontela (n.3) seria possível assinalar como os dois polos da relação, de um lado o silêncio e o branco e, de outro, o rumor e a primavera ${ }^{6}$ que se inter-relacionam no movimento mesmo da viagem que singra ("fende") o mar. Ocorre que o vocábulo "ânfora", escolhido como sinônimo de vaso (outra designação possível para navio), encarece o estrato feminino da metáfora, sobretudo se se considera que ela quem carrega consigo a "siderante impossível primavera", ou seja, a força geradora do florescimento.

Em "nada, esta espuma", de Ana Cristina Cesar, o feminino ("deusa", "sereia") se identifica com o outro, em clara posição simbólica de agente de fecundidade, no caso, poética: desejar o seios da sereia permite ser lido, portanto, como desejo de se deixar inspirar, poeticamente falando. Reconfigura-se, desse

6 Claro está que branco e primavera não são termos opostos, como silêncio e rumor. Entretanto, isso não pede que se estabeleça, pelo critério cromático, o contraste entre o branco e o multicolor da floração primaveril. 
modo, o canto feminino das sereias como aliciamento maligno do qual somente com enorme astúcia poder-se-ia resistir. No caso em questão as sereias podem ser aliadas.

Na modelagem hilstiana do topos, a dialética eu-tu aparece nitidamente demarcada: "palavras eu fiz nascer/Dentro da tua garganta" (versos 4 e 5); "As barcas afundadas. Minhas palavras./E doutas de ironia as tuas [palavras]/Só através da minha vida vão viver" (versos 11, 13 e 14). As palavras do outro sobre poesia são "finas", angulosas" e "de geometria", termos que fornecem as coordenadas para se compor o perfil racional desse tu a quem o eu poético se dirige na condição de detentora da palavra poética, uma vez mais, aqui, não apenas como equivalente de fecundidade mas também de imortalização ("luas de eternidade"): "Só através da minha vida vão viver". Isso aponta para uma possibilidade de se ler a relação entre o eu e tu, tal como ela aparece articulada no poema, como uma relação de interdependência em que o sujeito poético fecunda o outro que, por sua vez, vive através vida do eu lírico.

Fundo e superfície, lógica cartesiana e mistério contrapõemse no poema de Neide Archanjo lido anteriormente pela clave da metalinguagem. A permanecer nesse direcionamento de leitura, poderíamos conjecturar que a falta de alcance da consciência (ou a lógica cartesiana) que apenas arranha a borda das funduras ou "abismos", leia-se, as zonas mais recônditas da psique que é perscrutada no ato da criação poética, atestaria uma crítica aos atributos predominantes do masculino e uma valorização de seu oposto. Tal interpretação, que poderia ser endossada pelo fato de esse ser o único poema marcadamente de expressão lírica feminina, conforme assinalamos anteriormente, parece-nos, todavia, imperfeita, sobretudo se levarmos em consideração que 


\section{Rafael Quevedo}

o poema, na medida em que aborda o tema da criação poética, dimensiona as tensões entre superfície e fundura, o lógico e o alógico, dentro das circunscrições e limites do próprio eu. Desse modo, não nos parece possível compreender esse poema à luz de uma dialética eu-tu, linha adotada na interpretação dos textos anteriores. Tudo indica, portanto, que no poema em questão, é o inesgotável tema da escrita poética, abordado à luz da angústia íntima do poeta frente aos desafios que lhe impõe a criação, que Neide Archanjo toma para si. Esse mesmo tema reaparece, em outra obra sua, dessa vez em clave universalizante:

O navio desloca-se
grave e silencioso
em busca de seu país
o mar.
O poeta navega a página
com frio e medo
em busca do verso
que cedo não avistará.

(ARCHANJO, 1994, p. 136)

À exceção, portanto, do poema 7, os demais parecem pôr em questão, de algum modo, as relações que envolvem o agenciamento de forças que a metáfora náutica carrega consigo. Conforme assinalado a partir de Kathleen Martin em O livro dos símbolos, onde quer que a metáfora seja praticada, há sempre aquele elemento a quem é incumbida a função simbólica de capitanear as forças: da razão como disciplinadora das paixões ao poeta-timoneiro, é essa forma de equilibrar as tensões e forças, de estabelecer as relações entre o capitão e a "cooperação das partes" que aparece borrada nos poemas aqui comentados. Tal como vimos, das duas principais vias de abordagem do topos da navegação aqui discutidas (a saber: a metapoética e a amorosa), percebe-se uma tendência a se representar essas 
relações numa equação que envolve ajuste, equilíbrio de forças, "acordos tácitos" e entrecruzamento de subjetividades. Inegavelmente, o pequeno número de poemas que compõe o corpus destas considerações, bem como outras variantes, entre elas a ausência, no escopo deste trabalho, da análise da recente produção contemporânea de autoria masculina sobre o mesmo topos $^{7}$ impedem que afirmemos se se trata de uma variação propriamente feminina desse lugar-comum da tradição literária.

\section{Referências}

ARCHANJO, Neide. As marinhas. Rio de Janeiro: Salamandra, 1984.

ARCHANJO, Neide. Tudo é sempre agora. São Paulo: Maltese, 1994.

CAMÕES, Luís Vaz de. "Busque Amor novas artes, novo engenho". In.: MOISÉS, Massaud. A literatura portuguesa através dos textos. $31^{a}$ edição. São Paulo: Cultrix, 2006.

CARMINA BURANA [Canções de Beuern]. Tradução de Maurice van Woensel e apresentação de Segismundo Spina. São Paulo, Ars poética, 1994.

CARNEIRO, Geraldo. Por mares nunca dantes. Rio de Janeiro: Objetiva, 2000

CAMPOS, Haroldo de. Xadrez de estrelas: percurso textual. 1949-1974. São Paulo: Perspectiva, 2008.

CAYMMI, Dorival. "É doce morrer no mar". Dorival Caymmi (EP), Continental, 1943.

CESAR, Ana Cristina. "Cenas de abril” [1979]. In.: Poética. Companhia das letras, 2013.

7 Para ficar apenas em um único exemplo, vale lembrar o livro Por mares nunca dantes de Geraldo Carneiro de 2000. 
CODAX, Martin. "Ondas do mar de Vigo". In.: CORREIA, Natália. Cantares dos trovadores galego-portugueses. Lisboa: Editorial Estampa, 1998.

CORREIA, Natália. Cantares dos trovadores galegoportugueses. Lisboa: Editorial Estampa, 1998.

CURTIUS, Ernst Robert. Literatura europeia e Idade Média latina. Tradução de Paulo Rónai e Teodoro Cabral. São Paulo: Hucitec; Edusp, 2013.

DAL FARRA, Maria Lúcia. Alumbramentos. São Paulo: Iluminuras, 2012.

FONTELA, Orides. "Alba" [1983]. In.: Poesia Reunida [19691996]. São Paulo: Cosac Naify: Rio de Janeiro: 7Letras, 2006.

HILST, Hilda. “Amavisse”. In.: da poesia. São Paulo: Companhia das Letras, 2017.

HOLLANDA, Francisco Buarque de. "Mulheres de Atenas". Meus caros amigos (LP), Philips, 1976.

HORÁCIO. "Arte poética”. In.: ARISTÓTELES, HORÁCIO \& LONGINO. A poética clássica. Tradução de Jaime Bruna. São Paulo: Cultrix, 1981.

PALADAS DE ALEXANDRIA. Epigramas. Seleção, tradução e notas de José Paulo Paes. São Paulo: Nova Alexandria, 2001. PESSOA, Fernando. Mensagem. São Paulo: Martin Claret, 2001

PETRARCA, Francesco. Cancioneiro. Tradução de José Clemente Pozenato. Cotia: Ateliê Editorial, 2014.

RAMALHO, Christina. "As marinhas, de Neide Archanjo: um mergulho luso-brasileiro". In.: BRANDÃO, Izabel;MUZART, Zahidé L. (orgs.). Refazendo nós. Ensaios sobre mulher e literatura. Florianópolis: Ed. Mulheres; Santa Cruz do Sul: EDUNISC, 2003. 
MARTIN, Kathleen (editor). O livro dos símbolos. Reflexões sobre imagens arquetípicas. Taschen, 2012.

TRINGALI, Dante. Horácio poeta da festa: navegar não é preciso. São Paulo: Musa Editora, 1995. 